processing and activation of the cathodes, the thermionic devices were opened to the atmosphere, and then the coatings scraped away so as to expose the interface at the base metal. No special precautions have been taken to prevent reaction of the interface compound with the atmosphere.

$\mathrm{X}$-ray examination was carried out in most instances by glancing-angle reflexion technique, using copper $K \propto$ radiation and a circular camera of $19 \mathrm{~cm}$. diameter. In one or two instances the interfacial film was thick enough for filings to be made, but $\mathbf{X}$-ray analyses of such specimens did not yield results differing in any significant respect from that obtained by the surface reflexion technique.

The results are presented in tabulated form below :

\begin{tabular}{|c|c|c|}
\hline Base-metal & X-ray analysis & $\begin{array}{l}\text { Standard of comparison } \\
\text { made from : }\end{array}$ \\
\hline $\begin{array}{l}\text { Nickel with } \\
2 \text { per cent } \\
\text { aluminium }\end{array}$ & $\begin{array}{l}\text { Barium aluminate, } \\
\mathrm{BaO} . \mathrm{Al}_{2} \mathrm{O}_{3}\end{array}$ & $\begin{array}{l}\text { Equimolecular proportions } \\
\text { of } \mathrm{BaCO}_{\mathrm{s}} \text { and } \mathrm{Al}_{2} \mathrm{O}_{\mathrm{a}} \text { heated } \\
\text { to } 1,200^{\circ} \mathrm{C} \text {. in air }\end{array}$ \\
\hline $\begin{array}{l}\text { Nickel with } \\
0 \cdot 4 \text { per } \\
\text { cent silicon }\end{array}$ & $\begin{array}{l}\text { Barium orthosilicate, } \\
\mathrm{Ba}_{2} \mathrm{SiO}_{4}{ }^{*}\end{array}$ & $\begin{array}{l}\text { Mixture of } \mathrm{BaCO}_{2} \text { and } \mathrm{SiO}_{3} \\
\text { (finely ground flint) in } \\
\text { molecular ratio } 2: 1 \\
\text { heated to } 1,300^{\circ} \mathrm{C} \text {. in air }\end{array}$ \\
\hline $\begin{array}{l}\text { Nickel with } \\
0 \cdot 23 \text { per } \\
\text { cent titan- } \\
\text { jum }\end{array}$ & $\begin{array}{l}\text { Barium orthotitanate, } \\
\mathrm{Ba}_{2} \mathrm{TiO}_{4}\end{array}$ & $\begin{array}{l}\text { Mixture of } \mathrm{BaCO}_{8} \text { and } \mathrm{TiO}_{2} \\
\text { in molecular ratio } 2: 1 \\
\text { heated to } 1,300^{\circ} \mathrm{C} \text {. in } \\
\text { air. }\end{array}$ \\
\hline
\end{tabular}

* In Fineman and Eisenstein's paper the interface compound is stated to be "BaSiO ${ }_{3}$ " ; but after correspondence, they agree with the results reported here.

The accompanying photograph illustrates the X-ray identification of barium orthotitanate as the interface compound on an 'oxide' cathode in which a nickel-titanium alloy was the base metal.

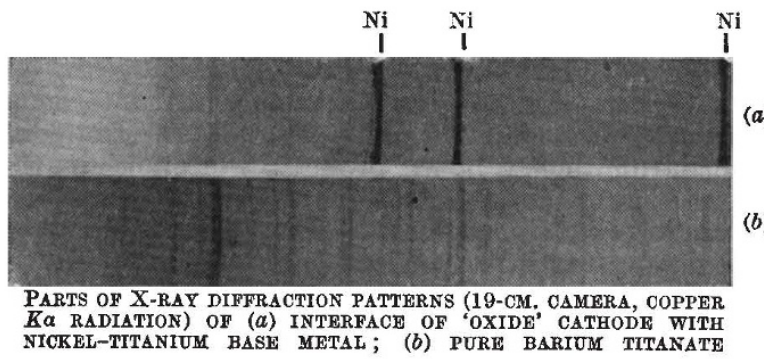

It is noteworthy that only barium compounds appear to be formed. There is no evidence that any solid solution of an isomorphous strontium compound occurs. This result is also obtained by Fineman and Eisenstein. It is known that isomorphous replacement of barium by strontium can occur with the orthosilicates and orthotitanates prepared for comparison purposes.

Another interesting crystallographic feature is that barium orthotitanate and barium orthosilicate appear to be structurally isomorphous. 'This is shown by the very close similarity in their Debye-Scherrer powder photographs. Of the two compounds the titanate has the larger lattice parameters. It is not known whether this crystallographic similarity has any significance so far as the thermionic behaviour is concerned.

Research Laboratories,

H. P. RooksBY

General Electric Company, Ltd., Wembley.

'Fineman, A., and Eisenstein, A, J. Appl. Phys., 17, 663 (1946).

${ }^{2}$ Benjamin, M., Phil. Mag., 20, 1 (1935).

Rooksby, H. P., J. Roy. Soc. Arts, 88, 318 (1940).

\section{Crystal Structure of $\mathrm{Co}\left[\mathrm{Hg}(\mathrm{CNS})_{4}\right]$}

AN X-ray investigation of $\mathrm{Co}\left[\mathrm{Hg}(\mathrm{CNS})_{4}\right]$ was undertaken in conjunction with work on similar compounds to determine the co-ordination of the complex ion.

The compound crystallizes in deep purple, tetragonal, prismatic needles of crystal class $\overline{4}\left(S_{4}\right)$ and space group $I \overrightarrow{4}\left(S_{4}^{2}\right) . \quad a=11 \cdot 09 \mathrm{~A} . ; \quad c=4 \cdot 37 \mathrm{~A}$. There are two molecules per unit cell.

From Patterson and Fourier syntheses of the $h k 0$ and $h 0 l$ zones, the co-ordinates of $\mathrm{Hg}$, Co and $\mathrm{S}$ are : $\mathrm{Hg}$ : $0,0,0$; Co: $\frac{1}{2}, 0, \frac{1}{4}$ or $\frac{1}{2}, 0, \frac{3}{4} ; \mathrm{S}: 0 \cdot 15,0 \cdot 13,0 \cdot 28$.

This gives an $\mathrm{Hg}-\mathrm{S}$ distance of $2.5 \mathrm{~A}$. It appears reasonably certain that the $\mathrm{S}$ atom is attached to the $\mathrm{Hg}$ in tetrahedral co-ordination, with $\mathrm{S}-\mathrm{Hg}-\mathrm{S}$ angles of $120^{\circ}$ and $104^{\circ}$.

The indications of the Fourier syntheses are that $\mathrm{S}-\mathrm{C} \equiv \mathrm{N}$ is straight, with $\mathrm{N}$ co-ordinated about $\mathrm{Co}$ (see diagram).

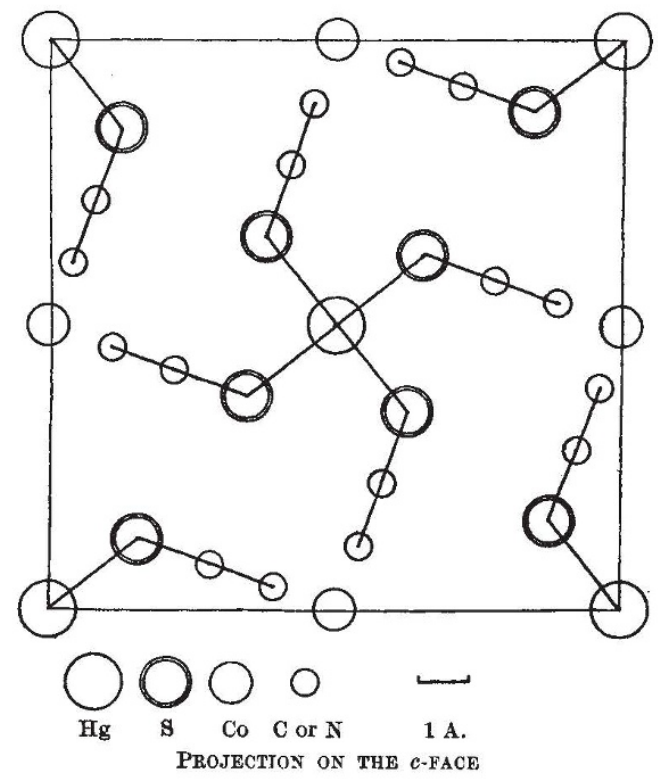

The investigation is being continued with the object of obtaining accurate co-ordinates for all the atoms.

Birkbeck College Research Laboratory,

J. W. JEFFERY

21-22 Torrington Square, London, W.C.l. Feb. 27.

\section{Effect of Shape of Operating Chamber in the Freeze-drying Process}

A RECENT communication ${ }^{1}$ discusses the freezedrying process as conducted with the pressure of permanent gas, and the vapour pressure of the ice on the condenser, maintained at very low levels. Research on the application of the process to foodstuffs is being conducted at the Low Temperature Research Station, Cambridge. It seemed likely that the need to operate at extremely low pressures might be undesirable economically in such applications, and accordingly other factors which affect the efficiency of the process have been investigated, including air pressures up to $1 \mathrm{~mm}$. mercury and condenser temper- 